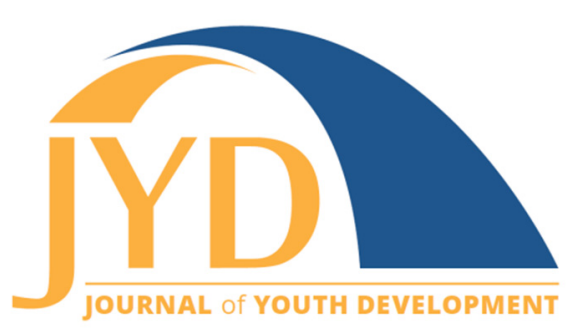

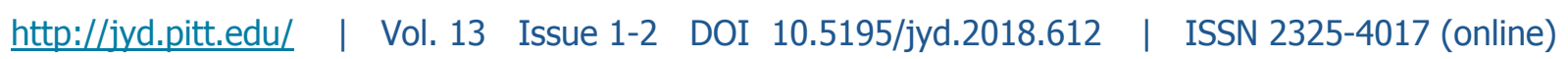

\title{
Learning Landscapes: The Education Spectrum from Camps to Classrooms
}

\section{Lance Ozier}

The City University of New York

lozier@ccny.cuny.edu

\begin{abstract}
Summer camps and school classrooms are intersecting institutions, both complementing the learning lives of young people. Each summer at camp children enjoy recreational, artistic, nature, and adventure programs that can help them acquire important skills that are not always or explicitly taught in the classroom. Campers practice sportsmanship, positive peer relations, social skills, and a sense of belonging. These activities develop the mindsets and noncognitive factors necessary to reduce summer learning loss and increase academic achievement when campers once again return to school as students in the fall. Including summer camps as a landscape on the education spectrum is essential to shaping more appropriate versions of teaching and learning - versions open to embracing and valuing all settings and the links that exist between these spaces.
\end{abstract}

Key words: summer learning, noncognitive, social justice, academic achievement, social emotional learning, teaching

\section{Camps and Classrooms}

I come from a long line of teachers. My father and two grandparents were classroom teachers before returning to the land and working in the family farm business. Even a great-grandfather had been a career teacher, spared from the family fields only when a farming mishap led to the amputation of a leg. For my great-grandfather, the loss of his leg meant the gift of school, and he went on to become a devoted math teacher who retired as a beloved high school principal. As a farm boy turned teacher myself, I have spent the better part of the last two decades in camps and classrooms. During those summers that turned into years, American summer camps have come to embody my thinking about the various learning landscapes on the education

(cc) EY New articles in this journal are licensed under a Creative Commons Attribution 4.0 License. This journal is published by the University Library System, University of Pittsburgh and is cosponsored by the University of Pittsburgh Press. The Journal of Youth Development is the official peer-reviewed publication of the National Association of Extension 4-H Agents and the National AfterSchool Association. 


\section{Education Spectrum from Camps to Classrooms}

spectrum. In fact, the word camp itself, from the Latin word campus, literally translated as field, provides an etymological link between school campuses and campsites-a literal landscape for learning.

In my 20 years working in education, I have found creativity and imagination to be ubiquitous in these less institutional, yet more intentional, camp settings, therefore offering a unique experience and opportunity for young people to explore, discover, and experiment. The creation of such a space where this is possible for children, in whom new meanings and understandings emerge, results from encountering both struggle and success. I believe permission for children to choose, challenge, and reflect-to actually risk risking-are too often lacking in structured classrooms. My learning at camps has been about meticulously observing the smallest moments and interactions; it is always about taking the time to notice the struggling sprigs of acorns working their way through the soil. This metaphor illuminates the slowness, perseverance, and curiosity necessary to understand how camps serve as a co-educator, as the attitudes and perceptions of the learner become much more open to the growing of knowledge and the advancement of information, skills, and procedures. This combination of risk and success, a soil in which children feel safe and comfortable with their attempts and mistakes, yields greater achievement and more productive outcomes.

Years ago, I began thinking and writing about camp as a locale for young people to grow and develop, specifically those children most underserved by society and schools. Peg Smith, past CEO of the American Camp Association described camp as a "classroom without walls-an expanded learning environment that plays a crucial role in the education and development of the whole child. By providing children with the opportunity to connect with nature, participate in human-powered activities, and benefit from personal and primary relationships, camp is helping the youth of today develop into the leaders of tomorrow" (2005). In recognizing such, camp must be more than a location for "summer learning," extending beyond into the realm of "lifelong learning." Each summer, thousands of camps and counselors create the conditions for millions of youth to develop a mindset open to the challenges of the $21^{\text {st }}$ century and the requisite skills to make a life, make a living, and make a difference.

\section{Educational Pioneers}

By the time Charles W. Eliot, former president of Harvard University, reportedly claimed at a meeting of Girl Scout leaders in 1922, "the organized summer camp is the most important step in education that America has given the world," camping in America already had a long history 


\section{Education Spectrum from Camps to Classrooms}

of embracing the educational value of the camp experience (Sharman, 1938). In the second half of the 1800s, nature enthusiasts and educators experienced the modern world around them as one of rapid, sometimes confusing, and potentially deleterious changes, and responded by recreating what they believed had been lost in the transition. Reminiscent, the campfires of the pioneers were scarcely cold when Frederick William Gunn, a schoolmaster in Connecticut, set out in 1861 with all his boys in the wilderness to found the Gunnery Camp-widely recognized as the first organized summer camp—at Welch's point, not far from New Haven (Eells, 1986; Joy, 1936; Solomon, 1930). Gunn was not alone in his role as educator-turnedcamp director. Contemporaries included Earnest Berkeley Balch who established Camp Chocorua in 1881. Mr. Balch deliberately planned his camp "to meet special educational needs," of campers (Gibson 1936; Sargent, 1935).

For all the camp-classroom connections, one question has, surprisingly, been often overlooked: What are the distinguishing and complementary characteristics of a camp and school education? Inspired by educators then, I now consider camp as what happens when you cross three distinct factors that all flourishing communities possess: supportive relationships, shared and personal responsibility, as well as a love for learning and continuous improvement. A recent New Yorker magazine article pointed out,

For nearly a century, public education in America has been influenced by two opposing pedagogical approaches: traditionalism and progressivism. Broadly speaking, in the traditional approach to education a teacher imparts knowledge to students through direct instruction, and embodies a disciplinary culture in which obedience is both prized and rewarded. The purpose of the classroom is to equip all students to meet measurable academic standards. At a progressive institution, a teacher develops a curriculum but urges students to treat it as a staging ground for their own intellectual discoveries, often through hands-on activities and group work. Allowances are made for differences in the way individual students learn. (Mead, 2017, para. 20).

Camp exemplifies that progressive setting, where campers experience nature, activities, and problems that allow or even necessitate them to learn through discovery.

John Dewey, perhaps the most well known American educator, never mentioned camps specifically, yet shared in the nostalgia for an earlier, pre-industrial era in which young 


\section{Education Spectrum from Camps to Classrooms}

Americans had purportedly been more meaningfully socialized within their communities. In widely read books such as The School and Society (1899) and Democracy and Education (1916), Dewey emphasized children's play as deeply meaningful in developmental terms, and he argued for a system of education better fitted to the needs of children. In Children's Nature: The Rise of the American Summer Camp, Leslie Paris (2008) documents that while Dewey focused on formal schooling, many other progressive educators "saw camps as superior environments...." In schools, they argued, "other pressures such as testing and the need to teach basic skills mitigated against creative play" (p. 237). In fact, Dewey's colleague at Teachers College, Columbia University wrote, "We learn what we live, only what we live, and everything we live... the camp can thus spread a more adequate ideal of education" (Kilpatrick, 1942).

\section{New Frontiers}

Carol Dweck's (2008) concept of mindset is a helpful tool for me to think about what camp as educator means. A "growth mindset" is the term psychologists have coined to name the beliefs about our capabilities to learn new and possibly difficult things, exerting tremendous influence on which paths we take in life. Psychologists have now learned that the brain is more like a muscle-it changes and gets stronger when you use it. In fact, scientists have been able to show just how the brain grows and gets stronger when you learn, and we now recognize that intelligence can be developed. In other words, the brain is malleable, and doing challenging activities is the best way to make the brain stronger and smarter (Blackwell, Trzesniewski, \& Dweck, 2007; Driemeyer, Boyke, Gaser, Büchel, \& May, 2008). At camp, I know every moment of every day of every summer contains challenges—big and small—for children and young people to meet new friends, get along with others, and take responsibility for their camp community.

If we take a peek inside the outside layer of the brain-called the cortex-we find billions of tiny nerve cells, called neurons. These nerve cells have branches connecting them to other cells in a complicated network. Synaptic communication between these brain cells is what allows us to think and solve problems, so when we learn new things, these tiny connections in the brain actually multiply and get stronger. Despite struggles, a growth mindset recognizes mistakes along the way as a natural and normal-an almost essential--- element of mastering new skills. The more the mind is challenged to learn by overcoming obstacles, the more our brain cells grow, and I suggest this research supports the notion of summer camps as a critical learning 


\section{Education Spectrum from Camps to Classrooms}

environment and co-educator alongside schools, since camps provide kids with a heavy dose of safe risk taking and challenges, making camp the ideal location for growing the brain.

Despite all evidence, I have observed a dialectic between recent research that supports normalizing struggle and embracing challenges on the one hand, and traditional classroom and school structures that prioritize standardized curriculum and assessments over mistake making on the other. However, I want to argue that camps and classrooms are more complementary, so that as struggle is normalized during the summer, students return to the classroom more willing to take scholastic risks: raising their hand, asking for help, embracing a harder problem or assignment despite an increased possibility of failure. Therefore, the camp program need not be academic in nature for the learning to establish new neurological structures that we then use in other environments to access new information and ideas. Over time, as the brain grows new structures, campers' persistence amid challenges to learn new skills and acquire additional abilities-such as the $21^{\text {st }}$ century competencies of communication, creativity, collaboration, and critical thinking-becomes easier. The result is a stronger, smarter brain.

\section{Summer Learning Loss and the Limitations of Seasonal Thinking}

Unfortunately, children whose brains are not engaged during the summer can suffer from "summer learning loss." For other children, camps and the summers they occupy have served as landscapes for learning for many generations. While schools have traditionally been charged with academically enhancing our capacity to live and work in an ever-changing society, camps have increasingly gained wide recognition as vital summer learning venues, most notably for those marginalized by society and underserved in the classroom. Interest in the seasonality of learning can be traced back to a review of thirty-nine studies completed by Cooper, Nye, Charlton, Lindsey, and Greathouse (1996), the oldest dating back to 1906 (White, 1906). These studies point to the same general conclusion: all young people experience learning losses when they do not engage in educational activities during the summer. In terms of standardized test results, the research is clear in concluding that students typically score lower at the end of summer vacation than they do on the same tests at the beginning of summer vacation (Cooper, et. al, 1996).

What I have noticed particularly during my years in the classroom is that students are often the objects rather than the subjects of teaching. Students who struggle are often objectified almost as a liability rather than considered active partners who help move the educational project of the school beyond the rhetoric of accountability, standards, and testing-mania. Education is 


\section{Education Spectrum from Camps to Classrooms}

perhaps the greatest civil rights issue of our time, and I worry that students who lack summer learning opportunities are often constructed as dis-abled--not enabled by the knowledge or experience or commitment of camp.

Yes, the challenge of summer learning loss is great. Yet, I want to suggest the solution is not more of the same in the form of an expanded school year, sentencing students to eight more weeks behind walls when we know they are just as likely to learn outside them. Camp has the capacity to imagine the spaces and traditional landscapes of learning differently. Many of today's teachers, on the other hand, driven by the demand for students to perform well on standardized tests, are left with little time for experiential curricula, much less for stimulating and challenging discussions about who young people are and want to become. Critical thinking and consciousness through education are at risk of becoming obsolete, and I think we have forgotten what it means to tolerate ambiguity, struggle with ideas, and search for answers that are not easy to come by. Schools' focus on academic achievement has outpaced our nation's need for empathy, collaboration, and an enduring sense of community and social justice.

\section{Learning to Learn}

A protege of Dewey, philosopher of education Maxine Greene, who was a teacher of mine, reminds us, "Education signifies an initiation into new ways of seeing, hearing, feeling, moving. It signifies the nature of a special kind of reflectiveness and expressiveness, a reaching out for meanings, a learning to learn" (Greene, 2001, p. 7). As I often discussed with Maxine, so much of schooling is clear-cut: standards are identifiable; answers can be looked-up; thinking is deferred. However, I believe it is in the struggle of learning to learn-in places like summer camp-where true education resides. "For us," Greene continues, "we are interested in education here, not in schooling. We are interested in openings, in unexplored possibilities" (p. 7).

In the same vein, a comprehensive review of learning outside the classroom finds the most effective youth development programs have both academic and recreational content. "Highquality programs also enable young people to examine various topics, skills, or projects that interest them deeply but may not be clearly linked to the school curriculum. Examination of this sort may also increase young people's capacity for creative thinking and problem solving" (Bridglall, 2005, pp. 42-43). Among and between the various spaces, settings, and landscapes for learning, young people desperately need time to negotiate with other children and adults the contradictions and complexities; to consider alternatives; and to identify the compelling. 
Each summer at camp, I observed children enjoying recreational, artistic, nature, and adventure programs that can help them acquire important skills that are not always or explicitly taught in the classroom. Campers practice sportsmanship, positive peer relations, social skills, and a sense of belonging. All of these "create positive social and psychological conditions for academic learning" when they once again return to school in the fall (Gordon et al., 2005, p. 43). Including summer camps as a landscape on the education spectrum is essential to shaping more appropriate versions of teaching and learning-versions open to embracing and valuing all settings and the links that exist between these spaces.

A few years back I conducted my own study with young people who had gone to summer camp for at least 6 or 7 years (Ozier, 2012). I asked them to talk about their camp experiences, and from their stories I identified convincing evidence that summer camp is an important place for kids to learn and grow. Recently, the skills campers in my study attributed to their camp experiences-confidence, leadership, social skills, independence, self-direction-have been described in books and articles as important noncognitive factors essential for success in the "new economy." For instance, a recent review of literature on the role of noncognitive factors in shaping school performance issued by the University of Chicago Consortium on Chicago School Research (Farrington et al., 2012) identified behaviors, attitudes, and strategies that are critical for success in school and in later life. These factors included attendance, work habits, time management, and competencies such as help-seeking behaviors, self-control, persistence, and social problem-solving skills that allow students to successfully manage new environments and meet new academic and social demands. If camp's purpose is to give kids a world of good, then camp seems a likely place for young people and adults to acquire and practice these important skills so they can imagine ways they might adapt to the challenges in an ever-changing world.

\section{Vision for the Future}

Rewind to my family-educator roots in fields and farms. Issues of equity are not lost in my opening description of my White ancestors' unearned privilege allowing them to obtain an education and become teachers, along with the right to own land and make their living on a farm. Our nation continues to face the residual implications of inequality, and camps have their own place in this history of injustice. We recognize that many camps contributed to or perpetuated prejudice in their early years, and that the industry has a vital role to play in leveling the playing field today. My emphasis here on social justice is what educational policy advocates refer to as the equality of educational opportunity. We must provide pathways for 


\section{Education Spectrum from Camps to Classrooms}

more young people to benefit from the summer camp experience, especially those children most underserved and marginalized by school systems and society. Camp communities open spaces for reciprocity, mutual interest, exchange, and shared privilege.

History is both a reminder of how much we have achieved and a motivator for overcoming our lingering limitations. Perhaps that is why the international education publication Phi Delta Kappan proclaimed, "In all probability the educationist of the year 2000 A.D. will look back upon us and wonder why we, the school people of 1938 , failed to include the camp as an integral unit of our educational system" (Patty, p. 113-114).

Moving forward, campers and counselors now confront multiple and complex issues about competencies, equality, and purpose. For these reasons, it is necessary not to think of summer camps simply as the fun factories that popular culture far too often suggests. Scott Brody (2013) said it best by suggesting "it is time to retire 'the magic of camp,"' recommending "we need to claim the word enrichment and take our place as educators," and adding the skills children need to succeed should be taught at camp "with rigor and intentionality-and [we should] measure our results" ("Our Unique Opportunity: Camp as Enrichment," para. 4-6). As we look forward to the next century of camping, it comes as no surprise to me that camper and staff experiences in intentional youth development communities are locations for all people to gain experiences that will lead them into bright futures. If we expect the next generation of youth to develop a mindset in which they identify deficiencies and seek to repair them, then summer camps must be recognized as key landscapes for children to learn and, as Maxine Greene (2012) said, "imagine how things should be and how they might be" (p. 185).

\section{References}

Blackwell, L. A., Trzesniewski, K. H., \& Dweck, C. S. (2007). Theories of intelligence and achievement across the junior high school transition: A longitudinal study and an intervention. Child Development, 78, 246-263.

Bridglall, B. L. (2005). After-school programs, youth development, and other forms of supplementary education. In E. Gordon, B. Bridglall, \& A. Meroe (Eds.), Supplementary education: The hidden curriculum of high academic achievement (pp. 35-62). Lanham, MD: Rowman \& Littlefield.

Brody, S. (2013, September/October). Teaching the skills that children need to succeed. Camping Magazine. Retrieved from www.ACAcamps.org/content/teaching-skillschildren-need-succeed 
Journal of Youth Development | http://jyd.pitt.edu/ | Vol. 13 Issue 1-2 DOI 10.5195/jyd.2018.612

\section{Education Spectrum from Camps to Classrooms}

Cooper, H., Nye, B., Charlton, K, Lindsay, J., \& Greathouse, S. (1996). The effects of summer vacation on achievement test scores: A narrative and meta-analytic review. Review of Educational Research, $66(3), 227-268$.

Dewey, J. (1899). The school and society. Chicago, IL: University of Chicago Press.

Dewey, J. (1916). Democracy and education: An introduction to the philosophy of education. New York, NY: Macmillan.

Driemeyer, J., Boyke, J., Gaser, C., Büchel, C., May, A. (2008). Changes in gray matter induced by learning—revisited. PLoS One, 3(7), e2669. doi:10.1371/journal.pone.0002669

Dweck, C. S. (2008) Mindset: the new psychology of success. New York, NY: Ballantine Books.

Eells, E. (1986). Eleanor Eells' history of organized camping: The first 100 years. Martinsville, IN: American Camping Association, Inc.

Farrington, C. A., Roderick, M., Allensworth, E., Nagaoka, J., Keyes, T. S., Johnson, D. W., \& Beechum, N. O. (2012). Teaching adolescents to become learners. The role of noncognitive factors in shaping school performance: A critical literature review. Chicago: University of Chicago Consortium on Chicago School Research.

Gibson, H. W. (1936). The history of organized camping: Pioneer camp personalities. Camping Magazine.

Greene, M. (2001). Variations on a blue guitar: The Lincoln Center Institute lectures on aesthetic education. New York, NY: Teachers College Press, Columbia University.

Greene, M. (2012). Rebellions, breakthroughs and secret gardens: The arts and imagination. In H. Kohl \& T. Oppenheim (Eds.) The Muses Go to School: Inspiring Stories about the Importance of Arts in Education. New York, NY: New Press.

Joy, B. E. (1936). The progressive camp program. Journal of Health \& Physical Education, 76), 368-400. Kilpatrick, W. H. (1942). The role of camping in education today. Minneapolis, MN: Burgess.

Mead, R. (2017, December 11). Two schools of thought. New Yorker. Retrieved from https://www.newyorker.com/magazine/2017/12/11/success-academys-radical-educationalexperiment

Ozier, L. (2012). Camp as educator: A study of summer residential camp as a landscape for learning and living. New York, NY: Teachers College Press, Columbia University.

Paris, L. (2008). Children's nature: The rise of the American summer camp. New York, NY: New York University Press.

Patty, W. W. (1938). Camps meet new needs. The Phi Delta Kappan, 21(4): 113-114.

Sargent, P. E. (1935). Sargent's handbooks: A handbook of summer camps; an annual survey. Boston, MA: Author.

Sharman, J. R. (1938). Camping, a school responsibility. The Phi Delta Kappan, 21(4): 113-114.

Smith, P. (2005). What is camp? American Camp Association. Reprinted by permission of the American Camp Association (C2018 American Camping Association, Inc. 
Journal of Youth Development | http://jyd.pitt.edu/ | Vol. 13 Issue 1-2 DOI 10.5195/jyd.2018.612 Education Spectrum from Camps to Classrooms

Solomon, B. (1930). Camping as a national movement. Camp Life, 2.

White, W. (1906). Reviews before and after vacation. American Education, 10, 185-188. 